\title{
Cyclosporine and Hepatitis C
}

\author{
Ryan Caballes $^{1}$, Mark W. Russo ${ }^{2 *}$ \\ ${ }^{1}$ Department of Medicine, Carolinas Medical Center, Charlotte, USA \\ ${ }^{2}$ Carolinas Medical Center, Charlotte, USA \\ Email: *Mark.Russo@carolinashealthcare.org
}

Received September 24, 2012; revised October 27, 2012; accepted November 7, 2012

\begin{abstract}
End stage liver disease from hepatitis $\mathrm{C}$ is a leading indication for liver transplantation. Recurrent hepatitis $\mathrm{C}$ after liver transplant may lead to cirrhosis and graft failure in up to $25 \%$ of recipients five years after liver transplantation. Antiviral therapy is challenging after liver transplantation due to increased side effects including cytopenias and decreased efficacy compared to the nontransplant population. Tacrolimus and cyclosporine are the most common immunosuppressants used to prevent graft rejection. Tacrolimus is more potent than cyclosporine and may be preferred to cyclosporine. However, cyclosporine may have activity against hepatitis $\mathrm{C}$ and may have a theoretical advantage to tacrolimus in hepatitis liver transplant recipients. Cyclosporine may inhibit NS5B and NS5A protein complexes and increase endogenous interferon activity. Cyclophilin inhibitors without immunosuppressive properties are under development and represent a novel mechanisms for inhibiting HCV replication.
\end{abstract}

Keywords: Immunosuppression; Liver; Transplant

\section{Introduction}

Hepatitis $\mathrm{C}$ virus (HCV) infects an estimated 170 million people worldwide and is the single most common indication for orthotopic liver transplantation (OLT) in Europe and the United States $[1,2]$. Indeed, end stage liver disease from hepatitis $\mathrm{C}$ is the indication for liver transplantation in approximately $40 \%$ of liver transplant candidates. Although up to $40 \%$ of patients who develop acute $\mathrm{HCV}$ infection may spontaneously clear infection; in contrast, after liver transplantation HCV reinfection post-transplant is universal [3-6]. An estimated $20 \%$ of liver transplant recipients with chronic $\mathrm{HCV}$ infection develop cirrhosis 4 - 5 years post-liver transplant $[6,7]$. The accelerated course of hepatitis $\mathrm{C}$ may be due age of the donor liver, gender, and viral properties, as well as immunosuppression [3,5,7-9].

\section{Hepatitis C Replication and Calcineurin Inhibitors}

$\mathrm{HCV}$ is a hepatotropic member of the flaviviridae family. The virus is transmitted parenterally and rarely through vertical and sexual transmission [4]. HCV possesses a positive strand RNA genome of about $9.6 \mathrm{~kb}$ in length. The genome encodes a polyprotein of about 3000 amino acids that is then cleaved by host and viral proteases to generate functional viral proteins, namely: core, two en-

"Corresponding author. velope proteins (E1 \& E2), and seven nonstructural proteins (p7, NS2, NS3, NS4A, NS4B, NS5A, and NS5B) $[4,10]$. The core and envelope proteins compose of an $\mathrm{N}$-terminal triad and are the major constituents of the extracellular virion and involved in viral assembly and entry. The nonstructural proteins NS3/NS4A, NS5A, NS5B are involved in viral replication and the target of direct acting antiviral agents [10]. The NS3/4A protein, a serine protease, and NS5B protein, RNA-dependent RNA polymerase are thought to play a central role in viral genome replication. NS2 is a protease that mediates the cleavage of the polyprotein at the NS2-3 junction. The $\mathrm{p} 7$ proteins form an ion channel thought to be critical for secretion of infection virus. [10].

The lack of a robust animal model hindered the development of therapy against $\mathrm{HCV}$, but the creation of the HCV replicon model overcame many of these limitations. HCV attaches to the host cell surface by utilizing at least four receptors, CD81, scavenger receptor class B type I (SR-BI), claudin-1 (CLDN1), and occludin (OCLN) [4]. HCV attaches itself to cells by low-affinity attachment to glycosaminoglycans and lectins. Then LDL receptors induce endocytosis and within the endocytic vesicle $\mathrm{HCV}$ is exposed to low $\mathrm{pH}$, that induces conformational changes and high affinity to receptors such as, CD81/SR-B1, TLR3 [11]. These steps are essential to the release of the virus in the cytoplasm of host cells.

Prior to the approval of cyclosporine (CsA) in the United States in 1983, survival rates for liver transplant 
recipients were less than $50 \%$. Steroids and azathioprine were the mainstay of therapy to prevent rejection. The development of calcineurin inhibitors (CNIs) revolutionized transplant medicine and after the introduction of cyclosporine survival rates increased to more than $70 \%$. Currently most patients undergoing OLT will receive either one of two such immunosuppressants, either tacrolimus (Tac) or (CsA) [1,9]. Calcineurin $(\mathrm{CN})$ is a calcium-dependent serine/threonine phosphatase that promotes $\mathrm{T}$ cell activation, by the expression of several cytokine genes, the most important interleukin-2 (IL-2), but also interleukin-4 (IL-4). Cyclosporine A was first isolated from the fungus Tolypocladium inflatum and has powerful immunosuppressive effects. Cyclosporins are cyclic peptides that have broad spectrum of biological activity. CsA binds to cyclophilin (Cyp) to form a binary complex that binds $\mathrm{CN}$ and inhibits its activity. Tacrolimus (Tac) is an immunosuppressant that attaches to FK binding proteins which then decreases calcineurin activity ultimately leading to immunosupression [5]. Tac is thought to be more potent than CsA, resulting in doses that are typically 25- to 50-fold less than CsA [12]. Although more potent, Tac-based and CsA-based regimen were thought to be comparable in terms of patient and graft survival in both OLT and living donor liver transplant $[13,14]$. Thus, both CsA-Cyp and Tac-FK complexes are both potent inhibitors of $\mathrm{CN}$ activity that ultimately lead to immunosupression via suppression of IL-2 synthesis.

Cyclosporine or tacrolimus are the most commonly used CNI's used after liver transplantation. The different molecular processes and properties leading to calcineurin inhibition may thus provide a theoretical basis for which each CNI may interact with viral components. Furthermore, the difference between Tac and CsA potency has influenced how they were used in the past. Indeed, Tac was previously preferred in patients with $\mathrm{HCV}$ infection due to its higher potency, thus further limiting the use of steroids [6]. This view started to change, however, due to early reports suggesting acceleration of $\mathrm{HCV}$ recurrence in Tac-based regimens. However, both CNI's are toxic to pancreatic islet cells, but Tac is more toxic possibly as a result of increased concentration in islet cells of tacrolimus compared to cyclosporine. Furthermore, HCV is a risk factor for diabetes. Although immunosuppression accelerates chronic hepatitis $\mathrm{C}$, and viral loads are known to increase with corticosteroid treatment $[2,6,12,15]$. The best regimen that balances the permissive effects of immunosupressants versus graft survival has yet to be determined.

\section{In Vitro Data of Cyclosporine and Hepatitis C}

Studies suggest that CsA inhibits HCV viral replication and increases endogenous interferon. In vitro data using the HCV subgenomic replicon system demonstrate an inhibitory effect of $\mathrm{CsA}$ on $\mathrm{HCV}$ protein expression and replication [8-11]. Cyclophilins interact with the NS5 protein complex. For example cyclophilin B interacts with the NS5B polymerase to directly stimulate RNA binding activity. By binding to cyclophilins, CsA may disrupt the CypB-NS5 complex formation and thus HCV replication in vitro [16]. However, the cyclophilins contributions and roles in the HCV life cycle remain to be determined.

Due the central role IFN- $\alpha$ plays in the control of $\mathrm{HCV}$ infection and the ability of HCV to suppress IFN- $\alpha$ production, it has been hypothesized that CsA may have an effect on IFN expression. Indeed, some authors have demonstrated that $\mathrm{HCV}$ replication was suppressed by CsA with associated elevated levels of endogenous IFN- $\alpha$. More specifically, Liu and colleagues report that CsA treatment of HCV JFH-1-infected Huh7 hepatocytes restored endogenous levels of IFN- $\alpha$ and also enhanced its expression but others found no evidence that either CsA or Tac interferes with IFN- $\alpha$-induced gene expression or antiviral activity $[5,15]$. In addition to effects of viral replication, CsA decreases the activation of intrahepatic fibroblasts induced by IL-4, thus reducing fibrosis in recurrent HCV [17]. It is thought that this may account for the observation in which Tac therapy was associated with higher probability of developing cirrhosis [11, 17]. CsA may enhance the production of TGF beta but studies have not consistently shown this.

By binding to host proteins, CsA is thought to mediate its antiviral effects. Other investigators further report that CypA is the isoform that serves as the essential cofactor for $\mathrm{HCV}$ replication and that the interaction of cyclophilins with NS5A seems to be the most critical [18]. Due to the high mutation rate of the HCV genome and relative stability of host cellular factors, new avenues for $\mathrm{HCV}$ therapy has involved targeting host proteins to further reduce drug-resistant HCV strains [16]. Currently, at least three CsA derivatives have shown anti-HCV effects by binding cyclophilins, namely: DEBIO-025, SCY635, and NIM811. Unlike CsA, however, these compounds possess a structural modification that interferes with $\mathrm{CN}$ but not Cyp binding [2]. Thus, these compounds are thought to be devoid of immunosuppressive activity that antagonize immune mechanisms for attaining SVR and may further simplify analysis of clinical trials by eliminating the permissive effects of immunosuppression on HCV replication.

Identifying the optimal immunosuppressive regimen is critical because recurrent $\mathrm{HCV}$ is a significant problem after liver transplant and treatment of post-transplant chronic HCV patients is plagued by lower rates of SVR (about 20\%), side effects and the potential for increased 
graft loss with use of alpha interferon (IFN) [5,15]. Thus, there remains potential for development of novel therapy for $\mathrm{HCV}$ for post-liver transplant recipients.

\section{Clinical Studies of Calcineurin Inhibitors and Hepatitis $\mathrm{C}$}

Initial comparisons by Wiesner, et al. suggest that long- term outcome was superior for Tac-based therapy in patients infected with HCV when compared to a regimen based on CsA [12,19] (Table 1). The secondary immunosuppressants used in the trial, however, varied considerably and was not controlled for in each arm. Indeed, steroid doses of the Tac-based arm were rapidly tapered to 5 $\mathrm{mg} /$ day by 3 months, and no other immunosuppressives

Table 1. Studies of cyclosporine and recurrent hepatitis C.

\begin{tabular}{|c|c|c|c|c|}
\hline Study (ref) & Design & $\mathrm{N}$ & Findings & Comments \\
\hline $\begin{array}{l}\text { Castells LL } \\
\text { et al. }[8]\end{array}$ & $\begin{array}{l}\text { Multicenter retrospective } \\
\text { study in } 14 \text { Spanish } \\
\text { transplant centers } \\
\text { comparing SVR and } \\
\text { relapse rates of patients } \\
\text { treated with PEG-IFN } \\
\text { and Ribavirin while } \\
\text { either on CsA or Tac } \\
\text { based regimen }\end{array}$ & 410 & $\begin{array}{l}\text { CsA arm achieved } 48 \% \\
\text { SVR compared to } 37 \% \text { in } \\
\text { Tac arm }(\mathrm{p}=0.37) \text { mainly } \\
\text { due to the lower relapse } \\
\text { rate in CsA group }\end{array}$ & $\begin{array}{l}\text { - Study is retrospective and any inherent } \\
\text { biases may not have been accounted for } \\
\text { - Important variables, such as CNI trough } \\
\text { levels, antiviral doses, and use of } \\
\text { adjunctive immunosuppressants were } \\
\text { analyzed only by a categorical variable } \\
\text { - Antiviral management with PEG-IFN } \\
\text { and Ribavirin may vary from center to } \\
\text { center and was not controlled in the } \\
\text { study. CsA mean trough levels (ng/mL): } \\
\mathrm{C}_{0}: 100-150 \mathrm{C}_{2}: 500-700 \\
\mathrm{Tac}^{\mathrm{T}} \text { mean trough levels }(\mathrm{ng} / \mathrm{mL}): 6-8\end{array}$ \\
\hline $\begin{array}{l}\text { Berenguer M } \\
\text { et al. }[12]\end{array}$ & $\begin{array}{l}\text { Randomized } \\
\text { single-center prospective } \\
\text { study comparing Tac vs. } \\
\text { CsA based regimen in } \\
\text { HCV positive recipients } \\
\text { undergoing OLT. Unless } \\
\text { otherwise severe, } \\
\text { treatment with PEG-IFN } \\
\text { and Ribavirin was } \\
\text { implemented after the } 1^{\text {st }} \\
\text { yr }\end{array}$ & 253 & $\begin{array}{l}\text { Rates of severe HCV, } \\
\text { bridging fibrosis or } \\
\text { cirrhosis, and cholestasis- } \\
\text { like hepatitis in the first } \\
\text { year were not significant } \\
\text { between the two arms } \\
\text { - Patient survival was also } \\
\text { found to be similar at } 1,3 \text {, } \\
\text { 5, and } 7 \text { years post OLT. } \\
\text { SVR were not significantly } \\
\text { different between the two } \\
\text { arms }\end{array}$ & $\begin{array}{l}\text { Relatively small sample size with a } \\
\text { calculated statistical power of } 6 \% \\
\text { CsA trough levels }(\mathrm{ng} / \mathrm{mL}): \\
1^{\text {st }} \text { mo: } 250-350 \\
2^{\text {nd }}-3^{\text {rd }} \text { mo: } 150-250 \\
4^{\text {th }} \mathrm{m} 0-1 \mathrm{yr}: 100-150 \\
>1 \mathrm{yr}: 100 \\
-\quad \text { Tac trough levels }(\mathrm{ng} / \mathrm{mL}): \\
1^{\text {st }} \text { mo: } 10-15,2^{\text {nd }}-3^{\text {rd }} \mathrm{mos}: 5-10 \\
>3 \text { mos: } 3-10\end{array}$ \\
\hline $\begin{array}{l}\text { Flisiak et al. } \\
\text { [22] }\end{array}$ & $\begin{array}{l}\text { Multi-center, } \\
\text { randomized, } \\
\text { double-blind, } \\
\text { placebo-controlled trial } \\
\text { designed to determine } \\
\text { whether DEBIO- } 025 \text { in } \\
\text { combination with } \\
\text { PEG-IFN- } \alpha 2 \text { a is safe and } \\
\text { efficacious at dosages of } \\
200 \mathrm{mg}, 600 \mathrm{mg} \text {, and } \\
1000 \mathrm{mg} \text {. } \\
\text { No CsA or Tac arm }\end{array}$ & 90 & $\begin{array}{l}\text { Dose of } 600 \text { and } 1,000 \\
\text { mg/day combined with } \\
\text { PEG-IFN- } \alpha 2 \mathrm{a} \text { induced a } \\
\text { significant drop in HCV } \\
\text { viral load in genotypes } 1 \text { \& } \\
4 \text { when compared to those } \\
\text { treated with PEG-IFN- } \alpha 2 \mathrm{a} \\
\text { alone }\end{array}$ & $\begin{array}{l}\text { - Small sample size since the study is in } \\
\text { Phase II clinical trial } \\
\text { It indirectly supports the in vitro data } \\
\text { suggesting that CsA have antiviral } \\
\text { effects. However, the study does not } \\
\text { completely rule out unforeseen } \\
\text { mech- anisms that may have arisen due } \\
\text { to structural modification of the parent } \\
\text { compound } \\
\text { Although PEG-IFN and Ribavirin was } \\
\text { the standard therapy at the time, } \\
\text { Ribavirin was not added to the dosing } \\
\text { scheme to simply analysis }\end{array}$ \\
\hline Wiesner [19] & $\begin{array}{l}\text { Multicenter RCT } \\
\text { comparing the efficacy } \\
\text { and safety of Tac and } \\
\text { CsA in primary OLT } \\
\text { recipients }\end{array}$ & $\begin{array}{c}529 \\
113 \text { with HCV }\end{array}$ & $\begin{array}{l}\text { - When stratified by } \\
\text { pre-OLT HCV exposure, } 5 \\
\text { yr patient survival rate in } \\
\text { Tac arm was significantly } \\
\text { longer than CsA arm (p = } \\
0.041)\end{array}$ & $\begin{array}{l}\text { - Secondary immunosuppressants were not } \\
\text { controlled for each arm } \\
\text { CsA group received an overall greater } \\
\text { dose of steroids } \\
\text { - Maintenance trough levels declined } \\
\text { gradually; 5-yrs post transplant } 80 \% \text { of } \\
\text { individuals have the following trough } \\
\text { levels (ng/mL): } \\
\text { CsA: } 75-328 \text { Tac: } 2.5-14.8\end{array}$ \\
\hline $\begin{array}{c}\text { Ghobrial et al. } \\
{[20]}\end{array}$ & $\begin{array}{l}\text { Retrospective analysis } \\
\text { that compared effect of } \\
\text { CsA vs. Tac based } \\
\text { regimen after a primary } \\
\text { OLT }\end{array}$ & $\begin{array}{l}340 \text { total } \\
\text { patients in both } \\
\text { arms, however, } \\
\text { only } 10 \\
\text { patients were } \\
\text { re-transplanted } \\
\text { due to recurrent } \\
\text { HCV. }\end{array}$ & $\begin{array}{l}\text { - Re-OLT for recurrent HCV } \\
\text { slightly lower in Tac arm } \\
(\mathrm{n}=3 ; 2.6 \%) \text { compared to } \\
\text { CsA arm }(\mathrm{n}=7 ; 3.9 \%) \\
\text { - } \text { Median time to recurrent } \\
\text { HCV requiring re-OLT is } \\
\text { earlier in Tac }(142 \pm 34 \\
\text { days) than in CsA }(787 \pm \\
\text { 805 days) }\end{array}$ & $\begin{array}{l}\text { - Subgroup analysis reported is too small } \\
\text { to draw any firm conclusions } \\
\text { - CsA and Tac Trough levels not reported }\end{array}$ \\
\hline
\end{tabular}


administered. The CsA arm, on the other hand, received greater doses of steroids. Thus, the observed differences may not have been related to the type of $\mathrm{CN}$-inhibitor, but rather due to drug dose, higher steroid doses in the CsA arms, and/or overall levels of immunosuppression $[6,12]$. Other early studies not primarily designed to compare $\mathrm{HCV}$ recurrence rates between $\mathrm{CsA}$ and Tac, such as those reported by Ghobrial et al. and a systematic review, however, suggested cyclosporine was associated with lower rates of HCV recurrence and better responses rates to antiviral therapy [20,21] (Table 1). The median time of HCV recurrence was significantly earlier in Tacbased immunosuppression than those based on CsA. A follow up study by the latter group, however, showed that the histological outcome of both groups after 7 years were similar [6]. More recently, a multicenter retrospective analysis suggests that CsA based therapy is associated with higher response rates to antiviral therapy in subjects on CsA based regimens compared to tacrolimus based therapy [8]. In this study, sustained virological response (SVR) and relapse rates among 410 patients who were treated with PEG-interferon and ribavirin post-OLT were assessed. The study showed that patients in the CsA arm achieved a $48 \%$ SVR and only $37 \%$ in the Tac arm $(p=0.037)$, which was largely due to the lower relapse rate with CsA group ( $p<0.001)$. Multivariate analysis demonstrated that there were no significant differences in factors associated with SVR between both arms. A meta-analysis of published data between 1993 and 2005 found that patient and graft survivals in post-OLT HCV positive patients were independent of the $\mathrm{CN}$ inhibitor used [21]. In an attempt to address this question, Berenguer et al. designed a single-center prospective study to assess the recurrence of HCV based on the initial CNI prescribed [11]. The authors reported the rate of severe hepatitis $\mathrm{C}$, those with bridging fibrosis or cirrhosis and those that developed cholestasis-like hepatitis in the first- year, were similar in both CsA and Tac arm. Thus, it is not surprising that SVR is not significantly different between the two CNIs with subsequent treatment with PEG-IFN and Ribavirin. Furthermore, patient survival at 1, 3, 5, and 7 years were similar in the CsA and Tac based regimen. The major limitation of this study, however, is the relatively small sample size $(\mathrm{n}=$ 253). Data from retrospective studies provide the rationale for performing larger well-designed randomized prospective studies that compare hepatitis $\mathrm{C}$ recurrence rates after liver transplant between tacrolimus and cyclosporine based regimens [3].

\section{Future Directions}

The approved protease inhibitors for genotype 1 patients in the US and Europe, telaprevir and boceprevir, used in combination with peginterferon and ribavirin have sub- stantially improved sustained viral response rates in the nontransplant population. These agents significantly increase tacrolimus and cyclosporine levels and ongoing clinical trials will study pharmacokinetics, drug interactions, and efficacy. DEBIO-025 is a cyclophilin under development without immunosuppressant properties but has in vitro and in vivo anti-HCV properties [22]. Flisiak et al. designed a 4-week, multicenter, randomized, double-blind, placebo controlled phase II trial to determine the antiviral properties of DEBIO-025 with PEG-IFN $\alpha$ $2 \mathrm{a}$ in nontransplant, treatment naïve patients with chronic $\mathrm{HCV}$. The effect of DEBIO-025 at three different doses in combination with pegylated interferon $\alpha 2 \mathrm{a}$ on $\mathrm{HCV}$ viral load of varying doses of DEBIO-025 in combination with $180 \mu \mathrm{g} /$ week PEG IFN- $\alpha 2 \mathrm{a}$ was compared to PEG IFN- $\alpha 2 \mathrm{a}$ and ribavirin The investigators found that a dose of 600 and $1000 \mathrm{mg}$ /day when combined with PEG INF- $\alpha 2$ a induced a statistically significant additive drop in HCV viral load in genotype 1 and 4 compared to PEG IFN- $\alpha 2 \mathrm{a}$. Furthermore, the safety profile of the combination therapy is similar to that observed in the standard of care arm.

Although in vitro data suggest the should be a benefit of cyclosporine over tacrolimus in hepatitis $\mathrm{C}$ liver transplant recipients, clinical studies have not shown that hepatitis $\mathrm{C}$ recurrence is significantly lower in recipients treated with cyclosporine. Furthermore, the development of DAA's has changed the efficacy and side effect profile of treatment and the impact of these new classes of agents and interaction with CNI's needs further study. Thus, cyclosporine can not be routinely recommended for hepatitis $\mathrm{C}$ recipients. Another exciting class of agents are cyclophilin inhibitors, and if proven to be safe and effective, CsA-derivatives may prove to be an important part of the regimen for liver transplant recipients infected with $\mathrm{HCV}$.

\section{REFERENCES}

[1] F. Fernandes, I. H. Ansari and R. Striker, "Cyclosporine Inhibits a Direct Interaction between Cyclophilins and Hepatitis C NS5A," PloS One, Vol. 5, No. 3, 2010, Article ID: e9815. doi:10.1371/journal.pone.0009815

[2] A. Scribner, D. Houck, Z. Huang, S. Mosier, M. Peel and B. Scorneaux, "Synthesis and Biological Evaluation of [D-Lysine] Cyclosporin A Analogs as Potential AntiHCV Agents," Bioorganic \& Medicinal Chemistry Letters, Vol. 20, No. 22, 2010, pp. 6542-6546. doi:10.1016/j.bmcl.2010.09.036

[3] M. Berenguer, A. Royuela and I. Zamora, "Immunosuppression with Calcineurin Inhibitors with Respect to the Outcome of HCV Recurrence after Liver Transplantation: Results of a Meta-Analysis," Liver Transplantation, Vol 13, 2007, pp. 21-29.

[4] J. Gentzsch, B. Hinkelmann, L. Kaderali, H. Irschik, R. Jansen, F. Sasse, et al., "Hepatitis C Virus Complete Life 
Cycle Screen for Identification of Small Molecules with Pro- or Antiviral Activity," Antiviral Research, Vol. 89, 2011, pp. 136-148. doi:10.1016/i.antiviral.2010.12.005

[5] Q. Pan, H. J. Metselaar, P. de Ruiter, J. Kwekkeboom, H. W. Tilanus, H. L. Janssen and L. J. van der Laan, "Calcineurin Inhibitor Tacrolimus Does Not Interfere with the Suppression of Hepatitis C Virus Infection by Interferon$\alpha$," Liver Transplantation, Vol. 16, 2010, pp. 520-526.

[6] R. Teixeira, G. V. Papatheodoridis and A. K. Burroughs, "Management of Recurrent Hepatitis C after Liver Transplantation," Journal of Viral Hepatitis, Vol. 8, 2001, pp. 159-168. doi:10.1046/j.1365-2893.2001.00282.x

[7] A. Frankel, "Letter: In Response to Treatment of Psoriasis with Cyclosporine in Patients with Hepatitis C Infection: Risk or Opportunity?" Journal of the American Academy of Dermatology, Vol. 64, No. 4, 2011, pp. 788-789.

[8] ReViS-TC Study Group, "Cyclosporine A-Based Immunosuppression Reduces Relapse Rate after Antiviral Therapy in Transplanted Patients with Hepatitis C Virus Infection: A Large Multicenter Cohort Study," Transplantation, Vol. 92, No. 3, 2011, pp. 334-340.

[9] S. Pollard, "Calcineurin Inhibition and Disease Recurrence in the Hepatitis C Virus-Positive Liver Transplant Recipient," Liver International, Vol. 24, 2004, pp. 402206. doi:10.1111/j.1478-3231.2004.0987.x

[10] K. Watashi and K. Shimotohno, "Chemical Genetics Approach to Hepatitis C Virus Replication: Cyclophilin as a Target of Anti-Hepatitis C Virus Strategy," Reviews in Medical Virology, Vol. 17, 2007, pp. 245-252. doi:10.1002/rmv.534

[11] M. Berenguer, V. Aguilera, F. San Juan, S. Benlloch, A. Rubin, R. López-Andujar, et al., "Effect of Calcineurin Inhibitors in the Outcome of Liver Transplantation in Hepatitis C Virus-Positive Recipients," Transplantation, Vol. 90, 2010, pp. 1204-1209. doi:10.1097/TP.0b013e3181fa93fa

[12] G. Everson, "Impact of Immunosuppressive Therapy on Recurrence of Hepatitis C," Liver Transplantation, Vol. 8 No. 10, 2002, pp. S19-S27. doi:10.1053/jlts.2002.35852

[13] The US Multicenter FK506 Liver Study Group, "A Comparison of Tacrolimus (FK 506) and Cyclosporine for Immunosuppression in Liver Transplantation," New England Journal of Medicine, Vol. 331, 1994, pp. 1110-1115. doi:10.1056/NEJM199410273311702

[14] K. Tanaka, J. Lake, F. Villamil, G. Levy , P. Marotta, S. Mies, B. de Hemptinne and C. Moench, "Comparison of Cyclosporine Microemulsion and Tacrolimus in $39 \mathrm{Re}-$ cipients of Living Donor Liver Transplantation," Liver Transplantation, Vol. 11, No. 11, 2005, pp. 1395-1402. doi:10.1002/lt.20508

[15] J. P. Liu, L. Ye, X. Wang, J. L. Li and W. Z. Ho, “Cyclosporine A Inhibits Hepatitis C Virus Replication and Restores Interferon-Alpha Expression in Hepatocytes," Transplant Infectious Disease, Vol. 13, 2010, pp. 24-32. doi:10.1111/j.1399-3062.2010.00556.x

[16] X. Puyang, D. L. Poulin, J. E. Mathy, L. J. Anderson, S. Ma, Z. Fang, et al., "Mechanism of Resistance of Hepatitis C Virus Replicons to Structurally Distinct Cyclophilin Inhibitors," Antimicrobial Agents and Chemotherapy, Vol. 54, No. 5, 2010, pp. 1981-1987. doi:10.1128/AAC.01236-09

[17] A. Pissaia, L. Aoudjehane, S. Ben Othman, O. Scatton, O. Soubrane, C. Housset, et al., "Cyclosporine Inhibits Profibrotic Effects of Interleukin-4 and Transforming Growth Factor $\beta$ on Human Intrahepatic Fibroblasts Cultured in Vitro," Transplantation Proceedings, Vol. 42, 2010, pp. 4343-4346. doi:10.1016/j.transproceed.2010.09.124

[18] F. Yang, J. M. Robotham, H. Grise, S. Frausto, V. Madan, M. Zayas, et al., "A Major Determinant of Cyclophilin Dependence and Cyclosporine Susceptibility of Hepatitis C Virus Identified by a Genetic Approach," Public Library of Science: Pathogens, Vol. 6, No. 9, 2010, pp. 1-16.

[19] The United States FK506 Study Group, “A Long-Term Comparison of Tacrolimus (FK506) versus Cyclosporine in Liver Transplantation: A Report of the United States FK506 Study Group," Transplantation, Vol. 66, No. 4, 1998, pp. 493-499.

[20] R. M. Ghobrial, S. Colquhoun, H. Rosen, P. Hollis, S. Ponthieux, A. Pakrasi, D. G. Farmer, et al., "Retransplantation for Recurrent Hepatitis C Following Tacrolimus or Cyclosporine Immunosuppression," Transplantation Proceedings, Vol. 30, 1998, pp. 1470-1471. doi:10.1016/S0041-1345(98)00320-0

[21] R. Rabie, K. Mumtaz and E. L. Renner, "Efficacy of Antiviral Therapy for Hepatitis C Post Liver Transplant on Cyclosporine versus Tacrolimus: A Systematic Review and Meta-Analysis," Liver Transplantation, 2012, in press. doi:10.1002/lt.23516

[22] R. Flisiak, S. V. Feinman, M. Jablkowski, A. Horban, W. Kryczka, M. Pawlowska, et al., "The Cyclophilin Inhibitor Debio 025 Combined with PEG IFN $\alpha 2$ a Significantly Reduces Viral Load in Treatment-Naïve Hepatitis C Patients," Hepatology, Vol. 49, No. 5, 2009, pp. 1460-1468. doi: $10.1002 /$ hep. 22835 